\title{
Evaluation of endometrial polymerase chain reaction in diagnosis of female genital tuberculosis
}

\author{
Manvi Dua ${ }^{1 *}$, Kiran Pandey ${ }^{1}$, Sangeeta Arya ${ }^{1}$, Anil Verma ${ }^{2}$
}

\begin{abstract}
${ }^{1}$ Department of Obstetrics and Gynecology, GSVM medical College, Kanpur, Uttar Pradesh, India
${ }^{2}$ Department of Anesthesiology, GSVM Medical College, Kanpur, Uttar Pradesh, India
\end{abstract}

Received: 24 June 2019

Revised: 17 September 2019

Accepted: 04 October 2019

\author{
*Correspondence: \\ Dr. Manvi Dua, \\ E-mail: drmanvi@rediffmail.com
}

Copyright: (c) the author(s), publisher and licensee Medip Academy. This is an open-access article distributed under the terms of the Creative Commons Attribution Non-Commercial License, which permits unrestricted non-commercial use, distribution, and reproduction in any medium, provided the original work is properly cited.

\begin{abstract}
Background: Genital tuberculosis also known as tuberculous pelvic inflammatory disease can affect any age group, most common being reproductive women of 20-40 years. Clinical diagnosis of genital tuberculosis is a big challenge as the disease is either asymptomatic or has varied presentations. Conventional methods for diagnosis including AFB smear, endometrial histopathology and culture have limitations of low detection rate because of paucibacillary nature of disease. Laparoscopy generally detects macroscopic changes such as peritubal adhesions, tubercles and tuboovarian mass but it fails to diagnose disease at early stage. The objective of this study was to evaluate efficacy of TB DNA PCR in diagnosis of genital tuberculosis.

Methods: A total of 127 patients (between 2013-2016) who presented in gynecologic OPD with symptoms suggestive of tuberculosis were included in the study. All patients were subjected to endometrial histopathology and TB DNA PCR of endometrial tissue and peritoneal fluid. Since there is no gold standard test available for diagnosis of genital tuberculosis, a diagnostic criteria was adopted in the study based on laparoscopic findings, clinical history and other investigations. Patients were divided in two groups. Group A included patients positive of tuberculosis based on diagnostic criteria. Group B included patients negative for tuberculosis based on diagnostic criteria.

Results: In our study sensitivity of endometrial PCR, peritoneal PCR and endometrial histopathology were $73.8 \%, 17.8 \%$ and $10.7 \%$ respectively. Endometrial histopathology and peritoneal fluid PCR was found to be highly specific $(100 \%)$ while endometrial PCR was found to be $93 \%$ specific. Endometrial PCR although has highest sensitivity and specificity amongst the groups evaluated but high false negative rate was its major limitation.

Conclusions: No single test fulfills all criteria to emerge as sole diagnostic test, hence a high degree of suspicion with a detailed history and investigating with a variety of tests is all that is required to diagnose geniatal tuberculosis.
\end{abstract}

Keywords: Chronic pelvic pain, Genital TB, Infertility, Laparoscopy, Polymerase chain reaction, Sensitivity, Specificity

\section{INTRODUCTION}

Tuberculosis is a chronic infectious disease and morbidity associated with this condition has major health implications. Incidence of genital TB has been estimated to range from 1 to $26.7 \%$ in various studies from India. ${ }^{1,2}$ Incidence of genital TB varies greatly depending upon the geographical location ranging from $10.3 \%$ in India to being less than $1 \%$ in USA. ${ }^{3}$ It is endemic in India with an incidence of $58 \% .{ }^{4}$ Genital tuberculosis can affect any age group, most common being reproductive women of 20-40 years. Infertility, menstrual irregularities and chronic pelvic pain are the most common manifestations of female genital tuberculosis. ${ }^{5}$ Others included fever, 
ascites, irregular vaginal bleeding, chest pain and pain in the flanks. ${ }^{6}$ Genital tuberculosis appears to be an important and common cause of Asherman's syndrome in India, causing oligomenorrhoea or amenorrhoea with infertility. ${ }^{7}$ Fallopian tubes are the first and the most commonly affected genital organ followed by endometrium, ovary and cervix. It causes irreversible damage to the fallopian tubes leading to infertility which is difficult to treat both by medical and surgical methods. ${ }^{8}$ Endometrial involvement in genital TB is secondary to tubal involvement. It occurs in $50-80 \%$ of genital TB. Since, there is no way to take the fallopian tubes out, sampling from the ovaries and endometrium was suggested for the detection of female genital tuberculosis. ${ }^{9}$ Use of menstrual blood for bacteriologic or molecular diagnosis has been recommended but was reported to show low sensitivity. ${ }^{10,11}$ Granulomas in endometrial tissue biopsy are better seen in premenstrual phase or within 12 hours after onset of menstruation. Focal collection of chronic inflammatory cells or presence of proliferative endometrium in the premenstrual week in a patient with past history of TB in other parts of the body or a family history of TB would favour a diagnosis of female genital TB. ${ }^{12}$ Ovaries are involved in 15-25\% of cases. Presence of tubo-ovarian mass, tubo-ovarian cyst with adhesions surrounding them is found in such cases. Cervical tuberculosis occurs in 5$15 \%$ of cases while TB of vagina and vulva occurs in $1 \%$ of cases. Genital TB was an important aetiological cause in patients with unexplained infertility with repeated IVF failure. $^{4}$

Laparoscopy usually detects macroscopic changes such as peritubal adhesions, tubercles on the tubes and small tubo-ovarian masses that are commonly seen in chronic cases. Female genital tuberculosis also presents distinctive diagnostic challenges including subtle clinical manifestations that were over-looked in laparoscopy during early stages of infection. The presence of periovarian adhesions, cornual block, tubal beading, tubercles, intrauterine adhesions, and ostial fibrosis had very strong association with positive TB PCR. Total predictive value of endoscopic evaluation in diagnosis of genital TB was $42.52 \% .^{13}$

\section{METHODS}

\section{Inclusion criteria}

- The All patients who presented with infertility, menstrual disturbances, chronic pelvic pain, recurrent pelvic inflammatory disease refractory to conventional therapy were included in the study.

\section{Exclusion criteria}

- Antenatal patients, unmarried female and those with any other medical disorder were excluded from the study.
This is a prospective study conducted between 2013 to 2016.

The study was conducted on 127 female patients attending gynecologic OPD of UISEMH, Department of Obstetrics and Gynecology, GSVM Medical College, Kanpur. Detailed history and examination was done. All patients underwent investigations such as CBC, ESR, tuberculin test, chest X-ray and pelvic sonogram. Endometrial biopsy within 12 hours of menstruation and diagnostic laparoscopy on day 9 of menstrual cycle was done in all patients. Semen analysis and HSG was done only in patients presenting with infertility. Sample was taken from the endometrium especially from both cornual ends and sent for PCR amplification and histopathology. Diagnostic laparoscopy was performed to look for beaded tubes, tubal block, hydosalpinx, presence of any tubercles on the tubes and other pelvic viscera, pelvic adhesions and tubo-ovarian mass. During laparoscopy peritoneal fluid from pouch of douglas else peritoneal washings was collected and sent for DNA PCR for detection of mycobacterium tuberculosis.

\section{A diagnostic criteria adopted in the study is as follows}

Findings suggestive of tuberculosis on laparoscopy along with any one of the following findings: Past history of TB, Raised ESR, Positive mantaux. Based on diagnostic criteria patients were divided into two groups. Group A included patients positive for tuberculosis based on diagnostic criteria. Group B included patients negative for tuberculosis based on diagnostic criteria. Endometrial tissue was collected in two vials -one in $10 \%$ formalin and other in normal saline. Formalin fixed tissue was sent to pathology where routine processing was done and tissue was stained with hematoxylin and eosin and observed under microscope. Presence of caseating granulomas surrounded by lymphoid cells, plasma cells, lymphocytes and giant cells were diagnostic of tuberculosis. Tissue from normal saline vial was sent for DNA PCR.

\section{Statistical analysis}

Sensitivity, specificity, positive predictive value negative predictive value of different tests were calculated using standard formula.

\section{Polymerase chain reaction technique}

All the available molecular tests are based on the principle of polymerase chain reaction (PCR). PCR based diagnosis of TB has been evaluated to be useful and important in the detection of pulmonary as well as extrapulmonary TB. PCR assays targeting various gene segments such as $64 \mathrm{kDa}$ protein encoding gene4, the IS6110 element 5 and mpt646 have considerably reduced the delay in laboratory diagnosis for definitive mycobacterial detection. 


\section{Processing of samples}

The endometrial tissue was finely chopped using a sterile scalpel and homogenized manually in TE buffer (TrisEDTA $-10 \mathrm{mM}$ Tris. $1 \mathrm{mM}$ EDTA pH 8.0) until the solution became turbid. This was centrifuged at $11200 \mathrm{~g}$ for $20 \mathrm{~min}$. The supernatant was discarded and the pellet was processed for further studies. POD aspirate and urine samples were centrifuged at $700 \mathrm{~g}$ for $15 \mathrm{~min}$. Supernatant was discarded and the pellet was used to extract DNA.

\section{Isolation of DNA}

Pellets were re-suspended in $500 \mu \mathrm{l}$ of TE buffer by repeated pipetting. Then $50 \mu \mathrm{l}$ of $10 \mathrm{mg} / \mathrm{ml}$ of lysozyme was added, mixed well and incubated for one hour at 37 0C. To this, $70 \mu \mathrm{l}$ of 10 percent SDS (sodium dodecyl sulphate) and $6 \mu \mathrm{l}$ of $10 \mathrm{mg} / \mathrm{ml}$ of proteinase $\mathrm{K}$ were mixed and incubated for $10 \mathrm{~min}$ at $65^{\circ} \mathrm{C}$.After incubation $100 \mu \mathrm{l}$ of $5 \mathrm{M} \mathrm{NaCl}$ was added and mixed thoroughly. The samples were further incubated with $80 \mu \mathrm{l}$ of $\mathrm{CTAB} / \mathrm{NaCl}$ (Cetyl trimethyl ammonium bromide in sodium chloride) solution for $10 \mathrm{~min}$ at $65^{\circ} \mathrm{C}$. To this prepared sample approximately equal volume (700 - 800 $\mu \mathrm{l})$ of chloroform/isoamyl alcohol were added, mixed thoroughly and centrifuged for $10 \mathrm{~min}$. To the supernatant, 0.6 volume isopropanol was added to precipitate the nucleic acids and placed at $-200^{\circ} \mathrm{C}$ for 60 min. The resultant sample was spun at $16128 \mathrm{~g}$ for 20 $\min$ at $60^{\circ} \mathrm{C}$. The resulting DNA pellet was washed with 70 per cent ethanol to remove residual CTAB. The supernatant was carefully removed and the pellet was dried. The prepared pellet was re-dissolved in $25 \mu \mathrm{l}$ of TE buffer (910mM TRIS and $1 \mathrm{mM}$ EDTA) and stored at $40^{\circ} \mathrm{C}$ for future use.

\section{Amplification of mycobacterial DNA}

PCR was performed using gene amplification 9700 Thermal cycler with standard $25 \mu \mathrm{l}$ working volume. Precautions were taken to avoid false positivity. Preparation of PCR reagents, addition of template DNA and analysis of amplified products were done in three different rooms to avoid carry over contamination. Reagents were aliquoted and each aliquot was used only once. Wax beads were added to minimize nonspecific amplification. DNAs from the samples were amplified using the following primers.

- IS6110a (5’ - CCT GCG AGC GTA GGC GTC GG $\left.-3^{\prime}\right)$

- IS6110b (5’ - CTC GTC CAG CGC CGC TTC GG 3')

- TRC4 primer 1 (5' - GAC AAC GAC GTG CGCCTA CT - 3')

- $\quad$ TRC4 primer $2\left(5^{\prime}\right.$ - GAC CGA ATT AGC GTA GCTCC - 3')
- The IS6110 primers amplify a fragment with a length of $123 \mathrm{bp}$, while the TRC4 primers amplify fragment with a length of $173 \mathrm{bp}$

\section{Cycling parameters}

The reaction was performed on ice to minimize nonspecificity. The cycling parameter used was initial denaturation at $95^{\circ} \mathrm{C}$ for $5 \mathrm{~min}$, followed by denaturation at $94^{\circ} \mathrm{C}$ for $30 \mathrm{sec}$, annealing at $58^{\circ} \mathrm{C}$ for $30 \mathrm{sec}$, extension at $72^{\circ} \mathrm{C}$ for $30 \mathrm{sec}$ with 25 cycles and a final extension at $72^{\circ} \mathrm{C}$ for $5 \mathrm{~min}$. Detection of amplified products was done by agarose gel electrophoresis $(2 \%)$ at 80 volts for $45 \mathrm{~min}$. Gel was stained with ethidium bromide and viewed under UV transilluminator.

\section{RESULTS}

The present study assesses the role of PCR in the diagnosis of genital TB using endometrial and peritoneal samples. In our study 26-30 years was the most common age of presentation which correlates well with the results of other available studies. Infertility $(n=82,64.5 \%)$ was found to be the most common symptom followed by menstrual disorders $(\mathrm{n}=71,56 \%)$, chronic pelvic pain $(\mathrm{n}=52,41 \%)$ and refractory PID $(\mathrm{n}=18,14.1 \%)$. Abdominal pain and altered bowel habits were the least common presenting symptoms. Constitutional symptoms (fever, anorexia, weight loss) was present only in $16.5 \%$ $(\mathrm{n}=21)$ patients (Table 1$)$.

Table 1: Distribution of patients according to symptomatology.

\begin{tabular}{|lll|}
\hline Complaints & $\begin{array}{l}\text { No of patients } \\
(\mathrm{n}=127)\end{array}$ & $\%$ \\
\hline Infertility & 82 & $64.5 \%$ \\
\hline 0-3 years duration & $15(\mathrm{n}=82)$ & $18.2 \%$ \\
\hline 4-6 years duration & $39(\mathrm{n}=82)$ & $47.5 \%$ \\
\hline 7-9 years duration & $28(\mathrm{n}=82)$ & $34.3 \%$ \\
\hline Menstrual disorders & 71 & $56 \%$ \\
\hline Hypomenorrhea & $35(\mathrm{n}=71)$ & $49.2 \%$ \\
\hline Oligomenorrhea & $23(\mathrm{n}=71)$ & $32.3 \%$ \\
\hline Secondary amenorrhea & $10(\mathrm{n}=71)$ & $14 \%$ \\
\hline Menorrhagia & $3(\mathrm{n}=71)$ & $4.2 \%$ \\
\hline Chronic pelvic pain & 52 & $41 \%$ \\
\hline Refractory PID & 18 & $14.1 \%$ \\
\hline $\begin{array}{l}\text { Altered bowel habits } \\
\text { Constitutional symptoms } \\
\text { (fever, anorexia, night } \\
\text { sweats, weight loss) }\end{array}$ & 12 & $9.4 \%$ \\
\hline \begin{tabular}{l} 
Total \\
\hline
\end{tabular} & 21 & $16.5 \%$ \\
\hline
\end{tabular}

It was found that $62(73.8 \%)$ out of 84 patients (Group A) were found to be positive (true positive) on Endometrial Tissue PCR. Peritoneal fluid PCR and endometrial histopathology was found to be positive in $17.8 \%$ and $10.7 \%$ patients respectively. Thus, sensitivity of 
endometrial PCR was found to be higher than the other two. We concluded that $40(93.13 \%)$ patients were found to be negative when tested by endometrial tissue PCR (true negative) while peritoneal fluid PCR and histopathology could detect all the true negatives. Thus, endometrial histopathology and peritoneal fluid PCR were found to be $100 \%$ specific while endometrial tissue PCR specificity was moderately high $(93.02 \%)$ (95\% CI $80.9 \%-98.5 \%)$. Positive predictive value of histopathology, peritoneal fluid PCR and endometrial PCR was found to be $100 \%, 100 \%$ and $95.3 \%$ respectively but their negative predictive value were $36.4 \%, 38.3 \%$ and $64.5 \%$ respectively. False negative rate of $26.1 \%$ (22 patients in Group A) of endometrial PCR was found to be significantly high which was found to be major limitation of our study. Because of this high false negative rate it cannot be relied upon as sole diagnostic test. Endometrial histopathology and peritoneal fluid PCR was found to have high false negative rate of $89.2 \%$ and $82.1 \%$ respectively (Table 2, 3 ) which means that majority of patients will be missed if we rely only on one of these tests for the diagnosis. False positive rate of endometrial histopathology and peritoneal fluid PCR was found to be $0 \%$ which implies that no single patient may be falsely labelled as diseased. Thus there is minimum possibility of misdiagnosing the patient as suffering from genital tuberculosis when endometrial histopathology and peritoneal fluid PCR is used as diagnostic test but false positive rate of endometrial TB PCR was $6.9 \%$ which could be due to early disease with low number of bacilli or with latent infection which are picked by PCR when women are still asymptomatic and before the structural damage to the tube has taken place.

Table 2: Comparison of endometrial tissue PCR, peritoneal fluid PCR and endometrial histopathology with diagnostic criteria.

\begin{tabular}{|c|c|c|c|c|}
\hline $\begin{array}{l}\text { Endometrial tissue } \\
\text { PCR/diagnostic } \\
\text { criteria }\end{array}$ & $\begin{array}{l}\text { Group A } \\
\text { diagnostic criteria } \\
\text { positive (number) }\end{array}$ & $\begin{array}{l}\text { Group A diagnostic } \\
\text { criteria positive } \\
\text { (percentage) }\end{array}$ & $\begin{array}{l}\text { Group B diagnostic } \\
\text { criteria negative } \\
\text { (number) }\end{array}$ & $\begin{array}{l}\text { Group B diagnostic } \\
\text { criteria negative } \\
\text { (percentage) }\end{array}$ \\
\hline $\begin{array}{l}\text { Endometrial tissue PCR } \\
\text { positive }\end{array}$ & 62 (true positive) & $73.8 \%$ & 3 (false positive) & $6.97 \%$ \\
\hline $\begin{array}{l}\text { Endometrial tissue PCR } \\
\text { negative }\end{array}$ & 22 (false negative) & $26.2 \%$ & 40 (true negative) & $93.13 \%$ \\
\hline $\begin{array}{l}\text { Peritoneal fluid PCR } \\
\text { positive }\end{array}$ & 15 (true positive) & $17.8 \%$ & 0 (false positive) & 0 \\
\hline $\begin{array}{l}\text { Peritoneal fluid PCR } \\
\text { negative }\end{array}$ & 69 (false negative) & $82.1 \%$ & 43 (true negative) & $100 \%$ \\
\hline $\begin{array}{l}\text { Endometrial } \\
\text { histopathology positive }\end{array}$ & 9 (true positive) & $10.7 \%$ & 0 (false positive) & $0 \%$ \\
\hline $\begin{array}{l}\text { Endometrial } \\
\text { histopathology negative }\end{array}$ & 75 (false negative) & $89.2 \%$ & 43 (true negative) & $100 \%$ \\
\hline Total & 84 & 100 & 43 & $100 \%$ \\
\hline
\end{tabular}

Table 3: Comparison of endometrial PCR, peritoneal PCR and endometrial histopathology.

\begin{tabular}{|llll|}
\hline Diagnosis & Endometrial PCR & Peritoneal PCR & Endometrial histopathology \\
\hline Sensitivity & $73.8 \%$ & $17.8 \%$ & $10.7 \%$ \\
\hline Specificity & $93 \%$ & $100 \%$ & $100 \%$ \\
\hline Positive predictive value & $95.3 \%$ & $100 \%$ & $100 \%$ \\
\hline Negative predictive value & $64.5 \%$ & $38.3 \%$ & $36.4 \%$ \\
\hline P-value & $<0.0001$ & 0.0024 & 0.0278 \\
\hline
\end{tabular}

\section{DISCUSSION}

According to Sharma JB et al, most women presented with infertility $(90.6 \%$ primary $72.9 \%$; secondary $17.6 \%)$ while the rest had chronic pelvic pain $(9.4 \%)$. The mean duration of infertility was 6.2 years. A total of $49(57.6 \%)$ women had normal menses, while hypomenorrhea, oligomenorrhea, secondary amenorrhea and menorrhagia were seen in $25(30.1 \%), 3(3.5 \%), 5(5.9 \%)$, and 2
(2.4\%) women respectively. ${ }^{7}$ Sahu $\mathrm{C}$ et al, concluded that polymerase chain reaction (PCR) showed higher sensitivity and specificity than conventional techniques. ${ }^{14}$ Kumari $G$ et al analysed that there isn't any clear cut diagnostic value of the methods other than biopsy. ${ }^{15}$ Recently, the PCR method is known to have an important diagnostic value. Conclusively the data obtained from this PCR based investigation reflected that conventional methods of diagnosis namely, HPE, AFB smear and 
culture have low sensitivity. ${ }^{14}$ Endo TB-PCR had high specificity to diagnose GTB, as did laparoscopy. Laparoscopy may therefore be avoided in TB-PCRpositive patients for diagnosis but may still be required to rule out GTB in PCR-negative cases. ${ }^{16}$ PCR was found to be useful in diagnosing early disease as well as confirming diagnosis in clinically suspected cases. ${ }^{17}$ One should be cautious about false positivity by way of contamination, dead bacilli, previous infection or asymptomatic TB at other site. Thus, a combination of PCR with the other available technics is the best method of achieving sufficient sensitivity and specificity for the diagnosis of female genital tuberculosis. ${ }^{18}$ PCR showed good correlation with laparoscopic findings in diagnosis of female genital tuberculosis. ${ }^{14}$

\section{CONCLUSION}

Genital TB has varied presentations, difficult to diagnose on the basis of clinical history and examination. Conventional methods of diagnosis have several limitations. Newer molecular methods including endometrial polymerase chain reaction (PCR) showed higher sensitivity and specificity than conventional techniques. But it has high false negative rate of $26 \%$ which prevents it from emerging as sole diagnostic test. Peritoneal fluid PCR was found to be highly specific but it has very low sensitivity and it is invasive, hence endometrial PCR is found to be better route of investigation. Since no single test fulfills all criteria to emerge as sole diagnostic test, hence a high degree of suspicion with a detailed history and investigating with a variety of tests is all that is required to diagnose geniatal tuberculosis.

Funding: No funding sources Conflict of interest: None declared

Ethical approval: The study was approved by the Institutional Ethics Committee

\section{REFERENCES}

1. Mohakul SK, Beela VRK, Tiru P. Hysteroscopy findings and its correlation with latent endometrial tuberculosis in infertility. Gynecol Surg. 2015;12(1):31-9.

2. Gupta S. Pelvic tuberculosis in women. J Obstet Gynecol India. 1956;7:181-98.

3. Krishna UR, Sheth SS, Motashaw ND. Place of laparoscopy in pelvic inflammatory disease. J Obstet Gynaecol India. 1979;29:505-10.

4. Dam P, Shirazee HH, Goswami SK, Ghosh S, Ganesh A, Chaudhary K, et al. Role of latent genital tuberculosis in repeated IVF failure in the Indian clinical setting. Gynecol Obstet Invest. 2006;61:2237.

5. Shahzad S. Investigation of the prevalence of female genital tract tuberculosis and its relation to female infertility: an observational analytical study. Iran J Reprod Med. 2012;10(6):581-8.

6. Ghadiri K, Izadi B, Afsharian M, Vaziri S, Rezaei M, Namdari S. Diagnostic value of serological tests (IgA, IgG, IgM) against A-60 antigen in tuberculosis. Iranian J Clin Infect Dis. 2008;3(4):205-8.

7. Sharma JB, Roy KK, Pushparaj M, Gupta N, Jain SK, Malhotra N, et al. Genital tuberculosis: an important cause of Asherman's syndrome in India, Arch Gynecol Obstet. 2008;277(1):37-41.

8. Youssef LB, Chelli H, Belhadj A. Current anatomico-clinical aspects of genital tuberculosis in women. Apropos of 49 cases. J Gynecol Obstet Biol Reprod (Paris). 1985;14:59-65.

9. Punnonen R, Kiilhoma P, Meurman L. Female genital tuberculosis and consequent infertility. Int $\mathbf{J}$ Fertil. 1983;28(4):235-8.

10. Abebe M, Lakew M, Kidane D, Lakew Z, Kiros K. Female genital tuberculosis in Ethiopia. Int $\mathbf{J}$ Gynaecol Obstet. 2004;84:241-6.

11. Simon HB, Weinstein AJ, Pasternak MS. Genitourinary tuberculosis: clinical features in a general hospital population. Am J Med. 1977;63:410.

12. Malkani PK, Rajani CK. Endometrial tuberculosis. Indian. J Med Sci. 1954;8:684-97.

13. Baxi A, Neema H, Kaushal M, Sahu P. Assessment of endometrial TB PCR results with laparoscopic and hysteroscopic features. J Obstet Gynecol India. 2011;61(3):301-6.

14. Sahu C, Baveja CP, Manaktala U, Kamal V, Nidhi $\mathrm{G}$, Jha H. Correlation of different diagnostic tecnniques and laparoscopy with PCR in diagnosis of genital tuberculosis. J Biosci Tech. 2011;2(5):38592.

15. Kumari G, Goel D, Mishra S. Comparison of conventional and modern biomedical tools used for diagnosis of genital tract tuberculosis: an overview. IOSR J Pharm Biol Sci. 2013;7(4):19-24.

16. Jindal UN, Bala $Y$, Sodhi $S$, Verma S, Jindal $S$. Female genital tuberculosis: early diagnosis by laparoscopy and endometrial polymerase chain reaction. The Int $\mathbf{J}$ Tuber Lung Dis. 2010;14(12):1629-34.

17. Thangappah RBP, Paramasivan CN, Narayanan S. Evaluating PCR, culture and histopathology in the diagnosis of female genital tuberculosisIndian. J Med Res. 2011;134(1):40-6.

18. Rozati R, Roopa S, Rajeshwari CN. Evaluation of women with infertility and genital tuberculosis $\mathrm{J}$ Obstet Gynecol India. 2006;56(5):423-6.

Cite this article as: Dua M, Pandey K, Arya S, Verma A. Evaluation of endometrial polymerase chain reaction in diagnosis of female genital tuberculosis. Int J Reprod Contracept Obstet Gynecol 2019;8:4424-8. 